\title{
The geographic distribution of patents and value added across European
}

Citation for published version (APA):

Caniëls, M. C. (1998). The geographic distribution of patents and value added across European. MERIT, Maastricht Economic Research Institute on Innovation and Technology. MERIT Research Memoranda No. 003 https://doi.org/10.26481/umamer.1998003

Document status and date:

Published: 01/01/1998

DOI:

10.26481/umamer.1998003

Document Version:

Publisher's PDF, also known as Version of record

\section{Please check the document version of this publication:}

- A submitted manuscript is the version of the article upon submission and before peer-review. There can be important differences between the submitted version and the official published version of record.

People interested in the research are advised to contact the author for the final version of the publication, or visit the DOI to the publisher's website.

- The final author version and the galley proof are versions of the publication after peer review.

- The final published version features the final layout of the paper including the volume, issue and page numbers.

Link to publication

\footnotetext{
General rights rights.

- You may freely distribute the URL identifying the publication in the public portal. please follow below link for the End User Agreement:

www.umlib.nl/taverne-license

Take down policy

If you believe that this document breaches copyright please contact us at:

repository@maastrichtuniversity.nl

providing details and we will investigate your claim.
}

Copyright and moral rights for the publications made accessible in the public portal are retained by the authors and/or other copyright owners and it is a condition of accessing publications that users recognise and abide by the legal requirements associated with these

- Users may download and print one copy of any publication from the public portal for the purpose of private study or research.

- You may not further distribute the material or use it for any profit-making activity or commercial gain

If the publication is distributed under the terms of Article $25 \mathrm{fa}$ of the Dutch Copyright Act, indicated by the "Taverne" license above, 


\title{
The Geographic Distribution of Patents and Value Added Across European Regions
}

\author{
Marjolein C. J. Caniëls (MERIT)
}

August 1997

\begin{abstract}
Until recently, the geographic element of concentrations of economic activity and knowledge spillovers was almost completely disregarded by economic theory. Although space is a central concept in theories in the field of geography, geographers have not attached great value to technology as a motivating factor for clustering of economic activity. A pooled market of skilled labour and the availability of nontraded inputs are considered much more important as factors that induce the clustering of firms (Krugman 1991). Several recent studies for the US (among others Jaffe, Trajtenberg and Henderson 1993, Audretsch and Feldman 1994, Feldman 1994) examined the extent to which innovative as well as economic activity clusters spatially. Until recently there were no data available for Europe on this issue. By means of a new data set, namely regional patent data for Europe, this paper will try to identify differences in geographic concentration in patents (as a proxy for innovation) and manufacturing value added over several industries. Several statistical techniques will be used to gather information on the spatial pattern of variation in patents and manufacturing value added across European regions.
\end{abstract}

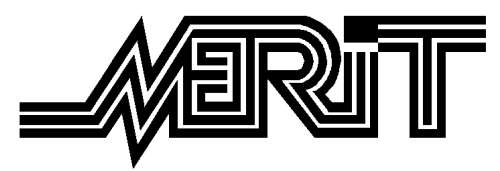

Maastricht Economic Research Institute on Innovation and Technology, University of Maastricht, P.O. Box 616, 6200 MD Maastricht, The Netherlands, tel +31 433883869 / 3877, fax +31 43 3216518, email m.caniels@merit.unimaas.nl 


\section{Introduction}

Many ancient civilizations knew prosperity due to important new ideas and the development of new products in the early days of their existence. This capacity to generate new ideas and develop them into products has been generating welfare and fortune for populations, since the beginning of time. Not surprisingly, many researchers (mainly economists) have been interested in how exactly the process of invention, development and the generation of prosperity materializes. However, until recently, the geographic dimension of this process of how new ideas lead to productivity, was almost completely disregarded by economic theory.

Nevertheless, among researchers a broad support exists for the belief that economic activity will concentrate geographically. Scale effects and proximity effects are at the origin of this. These insights come from the field of geography and regional economy. Although space is a central concept in theories of regional economists, these researchers have not attached great value to technology as a motivating factor for clustering of economic activity (see for example Krugman 1991). Therefore, not much research was done on spatial concentration of innovative activity in the field of regional economy. Among economists, only recently several studies have examined the extent to which economic activity as well as innovative activity clusters spatially. These studies are grafted upon the idea that knowledge spillovers take place and that they are, to some extent, locally bounded, meaning that locations nearby an innovative location will have a larger chance of receiving a knowledge spillover than locations far away. Over time a pattern of geographical agglomerations of innovative activities will occur.

The research until now mainly focuses on the United States simply because until recently for Europe no regional data were available on innovative activity. Several recent studies for the US (among others Jaffe, Trajtenberg and Henderson 1993, Audretsch and Feldman 1994, Feldman 1994) observe differences in spatial concentration of innovative activity and economic activity both across regions and across branches of industry. The object of the underlying study is to examine whether these spatial differences can also be observed across European regions. Specifically, the extent to which production and innovative activity is spatially concentrated will be examined as well as the degree to which geographic concentration varies across industries. A second goal of this paper is to examine whether the concentration of activity (innovative and economic) in a region is correlated to the concentration of activity in neighbouring regions, thereby taking the explorative analysis one step further by examining the extent to which the differences in innovative and economic activity can be assigned to the geographic location of the regions with regard to each other. The theoretical basis is that agglomerations of knowledge and economic activity attract even more innovative and economic activity to both the own region and the neighbouring regions. This cumulative process indicates the existence of knowledge as well as economic spillovers, in that a location with high growth will attract new industrial activity, new capital and knowledge and will become spatially more voluminous, like an oil spill on water. A technique used in spatial analysis will be applied to regional data to examine whether such a self-reinforcing feature occurs.

Section 2 will discuss some of the literature on clustering of innovative activity and production. Section 3 starts with a presentation of the data and the methodology used. Subsequently, in Section 4, an overview will be given of the spatial distribution of innovative activity and production as found in the data. Section 5 contains spatial analysis, paying atten- 
tion to spillover effects to neighbouring regions. The last section of this paper will give a brief summary of the results as well as some concluding remarks.

\section{Spatial concentrations of innovative activity and production}

A brief overview of the research done in the field of regional clustering starts with the theoretical arguments for the apparent clustering of innovative activity and economic activity. Several theories can be distinguished which try to explain clustering. The most straightforward and commonly known argument in support of clustering is the existence of economies of scale, which stimulate a firm to locate in one geographical location instead of several dispersed plants. The analogy with innovative activity can easily be made since innovative activity is also influenced by these forces. Therefore, firms tend to centralize their R\&D in one department. In addition, agglomeration economies induce innovative activities to cluster geographically. Agglomeration economies imply that positive externalities will occur when economic (as well as innovative) activity is located geographically close to each other. A spatial concentration of economic activity and people generates positive effects on productivity, because, for instance, the opportunity for communication of ideas and experience becomes much larger than in case of the absence of such concentrations. In this respect, the presence of private or public research institutes or universities could generate positive external effects. Acs, Audretsch and Feldman (1993), Audretsch and Feldman (1994) and Florida and Feldman (1994) found statistical evidence for this relation.

Furthermore, differences in productivity and innovativity among regions may be persistent rather than transitory. This argument is based on Myrdal's (1957) theory of circular and cumulative causation. The regional interpretation of this theory is that a region which starts with an economic or innovative advantage (for any reason), will go on to stay economically and innovative ahead of its neighbouring regions. Since these differences in productivity and innovativity will be persistent over time, a spatial pattern will occur that is characterized by spatial concentrations of production and innovation in certain regions. Similar to this line of thinking, Arthur (1990) argued that a series of historical events (eventually) results in a certain spatial pattern of innovative (and economic) activity. An initial specialization of a region in a certain innovative activity is reinforced, and a lock-in process causes innovative activities to concentrate spatially. The locational pattern of innovative and economic activity is therefore path-dependent.

The question arises whether empirical studies confirm the spatial concentration of innovative activity. Some early contributions (Muller and Nedjedly 1971; Buswell and Lewis 1970) present empirical evidence of regional R\&D concentrations in European countries. The former study is carried out for Czechoslovakia, while the latter focuses on the United Kingdom. In another study, Malecki (1980) documented the location of R\&D activities within the US. He concludes that industrial R\&D is concentrated in large urban regions.

More recent research focused on evidence from output measures of innovative activity for the US. Among others Acs, Audretsch and Feldman (1993), Audretsch and Feldman (1994) and Florida and Feldman (1994) conclude from the data provided by the United States Small Business Administration's Innovation Data Base (SBAIDB) that product innovations (as well as manufacturing production) are spatially concentrated.

Concerning empirical evidence of sectoral differences in spatial clustering (of innovativeness and production), Audretsch and Feldman (1994) find that "the spatial concentration of innovative activity in particular industries is considerably greater than for all of manufacturing" ( $\mathrm{p}$. 12). Especially the computer industry and pharmaceuticals display a large geographic con- 
centration. Breschi (1995), who examined patent data from the European Patent Office over the period 1978-1991 finds evidence of "quite large differences across sectors in the degree of spatial dispersion and asymmetries," (Breschi 1995, p.14). He notes that chemicalpharmaceutical and electrical-electronic sectors are characterized by high concentrations.

The remainder of this paper is devoted to spatial patterns of economic and innovative activity as they can be found in the EUROSTAT REGIO database. In doing so these data are combined with patent statistics developed on the basis of data of the European Patent Office.

\section{Description of the data}

The measurement of innovative activity is rather complex, since few indicators of innovativeness exist. Broadly speaking two groups of indicators can be distinguished. On the one hand R\&D expenditures (and other R\&D based indicators) which are commonly seen as input-indicators to the innovative process. Unfortunately, current regional R\&D statistics published by EUROSTAT (REGIO database) are not available for a comparison of different industrial sectors. Patents form another category of indicators of innovative activity. In contrast with R\&D statistics, patents are regarded as output indicators. An advantage of patent statistics is that they are disaggregated to the sector level. Therefore, the underlying study is based on patent statistics generated from data of the European Patent Office.

Using patents as a proxy for innovative activity also has several disadvantages, which will not all be discussed here. For a good survey of the problems and advantages of the use of patent statistics, see e.g. Scherer (1983) and Griliches (1990).

However, note that a problem of the use of patents in comparing industrial sectors is that the 'propensity to patent' varies across industries and across countries. The propensity to patent is proxied by dividing the amount of patents per unit by the amount of $R \& D$ expenditures in this unit. A unit can represent an industry, but also a country. The lack of disaggregated data on R\&D expenditures keeps us from envisaging differences between industries. It is commonly known, however, that traditional industries such as residential equipment and stone, clay and glass products, display a relative high propensity to patent (Scherer 1983, Feldman and Florida 1994). Table 1 gives an indication of the differences in the incidence to patent, among the countries under consideration. It is clear from this table that the Netherlands have a very high rate of patents versus R\&D expenditures, while Spain has an extremely low incidence to patent. However, these differences do not form a major concern, since the spatial distribution of patents over Europe still gives valuable information about the degree of innovativeness of a country or a region. The differences in the propensity to patent across countries - as proxied by patents divided by R\&D - can stem from several reasons. A country with a low propensity to patent can just be inefficient in generating innovations from $R \& D$. Another reason might be that $R \& D$ is merely used for imitation in stead of innovation in such countries. In either way, patents can be used as a proxy for innovativity.

The data on patents, used in this paper, stem from the European Patent Office and are based on the geographic location of the inventor of the patent. The use of patents allocated by the postal code of the inventor make it possible to trace innovative activity back to the region of origin. Another way to approach patent statistics is to use patents according to the location of the applicant. However, this approach is likely to be more biased in case of large companies, since patents are filed by the headquarters of a company, even though they might be developed in geographically distant subsidiaries. The object of this study is to get a grasp of the actual location of origin of knowledge in a certain field, making the use of inventors preferable over applicants. 
As a proxy for production, manufacturing value added at factor costs is taken. This gives a more accurate image of economic activity than value added at market prices, since in the latter subsidies and taxes are included, which might differ across countries. The decision to take value added at factor costs instead of e.g. Gross Domestic Product (GDP) was based on the fact that GDP data are not disaggregated into sectors.

The geographic unit of calculation are regions according to the NUTS classification. The size of the regions differs across countries, although not greatly, because the NUTS level was chosen such that differences in size are compensated ${ }^{1}$. An additional advantage of taking NUTS regions on the level chosen is that it is closely allineated to the administrative subdivision.

\section{Spatial distribution of patents and value added across European regions}

The analysis in this paper begins with an overview of the geographic distribution of patents and manufacturing value added in Europe over the years 1986-1990. As Figure 1 points out, the geographic distribution of patenting activity is highly concentrated across regions. High patenting activity is located in the north of Italy, with a branch to Rhone-Alpes and Paris, the south and west of The Netherlands and the south of the United Kingdom. Each of these regions perform at least two percent of European patenting. The top twelve of the regions accounts for about 70 percent of the total number of patents (Table 2), which indicates a high geographic concentration in only a few European regions. However, it should be kept in mind that the sample used in this paper does not include German regions ${ }^{2}$, even though recent studies (Verspagen 1997, Breschi 1995) have found that the most innovative regions of Europe are located in Germany. It is notable that Spain and the southern part of Italy display very little patent activity. Figure 2 shows that manufacturing value added also is concentrated across European regions, however, at first sight less than patents. This observation is affirmed by Table 2, which shows that about half of European value added is generated by the top twelve regions. Comparing the spatial location of concentration of patents and manufacturing value added (Table 2), only a few differences can be observed. Almost all regions appear on both listings, although they might differ in ranking. The regions that disappear from one of the listings turn up at the $14^{\text {th }}$ or $17^{\text {th }}$ rank if the complete listing is considered. This finding indicates that the most innovative regions are the same regions in which most of the European value added is generated.

However, the simple comparison of the amount of patents across regions is not entirely correct, because it ignores the fact that the size of the population (the manufacturing base) of some regions is larger than in other regions (Audretsch and Feldman 1994). Therefore, in Figure 3 the amount of patents of a region divided by the average population ${ }^{3}$ of the region over the 5 years under consideration (1986-1990) is compared to the European total amount of patents divided by the average of European population. Figure 4 does the same for manufacturing value added. The darkest areas in Figure 3 and 4 show regions which have a number of patents (value added) per head which is at least twice as high than the overall European ratio. The dark gray areas still have more than average patents (value added) per head. It can clearly be seen that the patentdata show more regions with extreme values (black and white areas) than the data for value added, which display a more dispersed pattern in the sense that almost all regions are gray. These findings indicate that value added is less concentrated than patenting. This is not a great surprise, since it is commonly known that research institutes (private as well as public) and $\mathrm{R} \& \mathrm{D}$ departments of large enterprises are not as widely spread as production. 
The conclusion that can be drawn from the data is that both patents and value added show some degree of concentration over Europe. However, when Figure 1 and Figure 2 are compared it can also be concluded that the location of the patent- and manufacturing value added-intensive regions does not differ greatly.

Although Figure 1 and 2 display the geographic distribution of innovative as well as economic activity in Europe, they aggregate across all industries and therefore overlook sectoral differences. The question arises whether differences exist when looking at a sectoral level.

An index that can be used to indicate whether a variable is distributed randomly or concentrated geographically is the Herfindahl index (formally defined as $\sum_{i=1}^{n} S_{i}^{2}$, where $S_{i}$ denotes the share of a variable of region $i$ in the total of the variable of a country and $n$ is the number of regions in a country). Since the extreme values of this index are dependent on the number of regions in a country, the Herfindahl index used in this paper is rescaled to bring it within the interval $[0,1]$ for every country ${ }^{4}$. Mathematically, this operation can be rewritten into the following equation:

$$
H F_{j}=1+\frac{\ln \sum_{i=1}^{n} S_{i j}^{2}}{\ln n},
$$

where $H F_{j}$ denotes the rescaled Herfindahl index for sector $j, S_{i j}$ denotes the share of a variable of region $i$ and sector $j$ in the total of the variable of a country in sector $j$. A value of one of the resulting index represents evidence of complete geographical concentration in one region, while a value of zero represents evidence of equal distribution of the variable under consideration.

When the Herfindahl is calculated for each industry in Europe ${ }^{5}$, the results differ for the geographic distribution of value added versus the geographic distribution of patents (Figure 5). It is again shown that patents display a higher degree of concentration than value added. However, value added shows more variety in concentration across sectors, while for patents all the sectors are concentrated to approximately the same extent. With regard to value added the sectors B42 (Textiles and clothing, leather and footwear) ${ }^{6}$ and B47 (Paper and printing) display a more than average geographic concentration. The geographic concentration of the population within Europe is also displayed in Figure 5. Comparing patent activity and value added to the concentration of the population (which is assumed to be evenly distributed across regions) one can observe that both variables display a higher concentration.

When we take a look at what the Herfindahl index tells us for the individual countries, we observe that within a country spatial concentrations of industries are more profound than within Europe as a whole, suggesting that at the country level more intensive clustering of activity of a sectors in a region takes place. Figure 6 displays the Herfindahl index for each sector within each available country. The horizontal line shows the Herfindahl index for population in each country. Notable is the large patenting concentration of the Spanish B42 sector (Textiles). The other Spanish industries are also very concentrated with regard to innovative activity. Within the Netherlands large differences between industries are visible. While B13 (Ferrous and non-ferrous ores and metals, other than radioactive) is highly concentrated with regard to patents as well as value added, B15 (Minerals) is as dispersed as population. Overall these results confirm the earlier results that within Europe value added is more dispersed than patents, while in most cases both variables are more concentrated than population. 
When Figure 6 is compared to Figure 5, it can clearly be seen that within countries sectors are much more concentrated than in Europe as a whole. For patents, and to a lesser extent also for value added, the European Herfindahl index is low compared to the country specific indexes. Preliminary findings for the Ginicoefficients ${ }^{7}$ for the different industries within Europe, reinforce these results.

Concluding, within Europe evidence is found of spatial concentration of sectors. However, within countries spatial concentrations of sectors are more profound. We would expect that at the event of a united Europe, one could already observe the concentration of industries in different parts of Europe. One would expect that firms already choose the best location among all European regions. Apparently, they do so only to a limited extent.

In order to pinpoint the location of country specific concentrations, Table 3 shows the three most important industries according to patenting and to value added in a country. Of each industry the three regions with the largest share in country total are displayed. It can be observed that industry concentrations differ among regions. For instance, the B24 sector (metal products) accounts for 64.4 percent of total patenting in France. Ile the France (FR1) has 47.6 percent of all French patents in this sector (corrected for population), thereby indicating that the metal products sector is largely concentrated within a few regions in France (the top 3 has 67.7 percent of total patents). It is notable that this sector only represents 31 percent of the total of the country value added. This again points to the feature that patenting is much more concentrated than value added. Note that Ile de France (the number one patenting region in this sector) only generates 28.2 percent of French value added in this sector. The other countries show similar distributions. From this table it can be concluded that innovative activities are highly concentrated in a single region within each country. The same, although to a lesser extent, holds for manufacturing value added.

The Revealed Comparative Advantage index (RTA) was calculated in order to give insight in the extent of the specialization of a region in an industry. This index is defined as $\left(P_{i j} / \sum_{j} P_{i j}\right) /\left(\sum_{i} P_{i j} / \sum_{i} \sum_{j} P_{i j}\right)$ where $P$ denotes the number of patents in region $i$ and sector $j$. To standardize this index to the interval $[-1,1]$ we calculate (RTA-1)/(RTA+1). For all regions documented in Table 4 the RTA reaches a value round and about 0.98 (not documented separately) which indicates considerable regional specialization.

In sum the analysis conducted so far has given several results. First, regions that belong to the most innovative ones in terms of patent activity, are also most productive in terms of manufacturing value added. Second, production is more dispersed than innovative activity, however, both are spatially concentrated (when compared to the distribution of population) across European regions. With respect to patenting, all sectors are concentrated to approximately the same extent at the European level, while manufacturing value added shows clear differences in sectoral concentration. Third, at the country level clustering of sectors occurs to a higher extent than at the European level. Geographic patterns of innovativity as well as production differ across sectors at the country level, suggesting that country specific factors in combination with sector specific factors play an important role in determining the geographic pattern of innovativity and production across countries.

\section{Spatial analysis}

In order to observe the spatial dispersion of a variable, concentration indexes like the Herfindahl index and/or the Ginicoefficient are used. However, these indexes only show the degree of concentration of a variable. They give no information about the degree in which the 
value of a variable in one region is spatially correlated with the value in neighbouring regions, therefore they cannot identify a concentration in a cluster of several regions located close together. A technique well-known in geography is spatial autocorrelation (Cliff and Ord 1973). This technique enables us to identify a significant non-random arrangement in an area pattern of a certain variable. In Figure 5 an example is given of positive and negative spatial autocorrelation. The basic property of spatially autocorrelated data is that the values are distributed non-randomly or are interdependent over space. The clustered pattern exhibits positive spatial autocorrelation, with neighbouring locations having similar values. The dispersed pattern has negative autocorrelation, with nearby locations having dissimilar values. Random area patterns have no spatial autocorrelation (McGrew and Monroe 1993). The advantage of the concept of spatial autocorrelation over the Herfindahl index or Gini coefficients is that it allows us to identify clustering patterns which spread out over the region borders, i.e. a concentration in several regions close together. It shows whether or not a group of neighbouring regions develop patents in the same classes or generate value added in the same sectors. If it is the case that geographic distance matters for knowledge spillovers, we would expect to find significant clustering, indicated by the presence of significant spatial autocorrelation. The extent to which this clustering takes place, however, could differ across industries.

Spatial autocorrelation can be measured using the coefficient of Moran. This coefficient is defined in the following way:

$$
I=\left(\frac{n}{W}\right) \frac{\sum_{i=1}^{n} \sum_{i \neq j}^{n}\left(w_{i j} z_{i} z_{j}\right)}{\sum_{i}^{n} z_{i}^{2}},
$$

where $z_{i}=x_{i}-\bar{x}$ ( $x_{i}$ is the value of the variable under consideration in region $i, \bar{x}$ denotes the average value of the variable over all regions) and $W=\sum_{i=1}^{n} \sum_{i \neq j}^{n} w_{i j}$ (Cliff and Ord 1973). $n$ points to the total number of regions and $\mathrm{w}_{\mathrm{ij}}$ denotes the element on the $i$ th row and $j$ th column of the matrix of $n$ times $n$ weights. The $n \times n$ matrix of weights is crucial to this statistic. In this matrix, a neighbouring region (in the sense that both regions share one border) is assigned a weight of $1\left(w_{i j}=1\right)$. For example, in the classification used in this paper The Netherlands consist of 4 regions (namely North, South, West and East). Region 1 (North of the Netherlands) and 2 (East) share a border, therefore their connection gets weight 1. Regions which do not share a border but are still closely located to region 1 (for example South of the Netherlands, which not shares a border with the North) are given a weight by using the concept of nearest neighbours, which means that a different (lower) weight is attributed to a second order neighbour. A second order neighbour does not share a border with region 1 , but does share a border with a neighbour of region 1 . It is very important to notice that no judgment of relative importance of the connection between regions, based on ex ante known information (for example the presence of roads and railways) should be within this matrix. The matrix is established such that it only reflects geographical distances. After establishing the orders of all neighbours, the corresponding matrix of weights is determined using the inverse of the orders. Thus the connection between region North and South of the Netherlands from the example gets weight $1 / 2$. By taking the inverse orders the relation between geographical distance $(g)$ and weight becomes $1 / g$, assuming that the higher the geographical distance, the influence of region on another one becomes increasingly less ${ }^{8}$. 
The resulting index $I$ has characteristics similar to the Durbin - Watson statistic for autocorrelation. The coefficient is approximately normally distributed when the number of regions is larger than 20. This index will be used as a proxy for geographic clustering of a variable.

In Figure 6 the results for the evolution over time of the coefficient of Moran for the total of all sectors is shown. No appreciable trend can be identified. The importance of spillovers stays the same throughout time. Therefore, for the rest of this paragraph attention will only be paid at the 5 year period of our sample (1986-1990).

In Table 4 the coefficient of Moran for patents and value added (corrected for population) are compared. The table indicates that patents show a respectable degree of spatial autocorrelation in almost all sectors. Looking at value added, significant autocorrelation can only be found in four sectors, indicating that the geographic clustering plays a more important role in innovative activity than in the generation of value added.

With respect to patents the data allow us to desaggregate to ISIC classes in order to observe the origin of the significance of the Moran coefficient in the broader NACE classification. Table 5 clearly shows the sectors for which a significant coefficient of Moran is found, indicating that these sectors are clustered over region borders. It is notable that sectors which are significant under the NACE classification are composed of ISIC sectors which are not unanimous significant. This leads to the impression that when certain ISIC sectors with a low coefficient of Moran are grouped together in the NACE classification, a higher coefficient of Moran might occur simply because these different ISIC sectors are located in regions close together. Thus, the whole spectrum of chemical ISIC sectors (ZCC, ZCD, ZCP and ZLR) might group together in one location, which causes a high coefficient of Moran for the Chemicals sector in the NACE classification (B17), while the individual ISIC sectors do not display high clustering over regions, simply because they prefer to be located to other chemical sectors rather than to their own sector.

It is notable that high-tech sectors like ZHO (Office machines and computers), ZCD (Pharmaceuticals) and ZEC (Communication equipment and semiconductors) display a very low coefficient of Moran (which is not significant), indicating that within Europe there is little clustering of these sectors in a group of regions located close to each other. This impression in reinforced when the coefficient of Moran is determined for a different grouping of ISIC sectors which can be labeled as high-tech, medium-tech and low-tech. Table 5 points out that high-tech sectors display the lowest degree of clustering, in contrast to medium and low-tech sectors in which spatial clustering is more profound. Probably the clustering in high-tech sectors is very intensive and will therefore not cover a group of regions, but stay within one region. The Herfindahl index could give some more information on this issue. From Figure 9 can be seen that indeed all high-tech sectors display very high concentration across European regions. In fact, all sectors (except shipbuilding, which is spatially dependent on a seabounded region and electrical machinery, which could be perceived as high-tech) display a lower geographic concentration than the high-tech sectors, indicating that high-tech is indeed concentrated in only several regions in Europe.

From the spatial analysis can be concluded that economic as well as innovative activity clusters within groups of contiguous regions. At the sectoral level clear differences appear. It has been shown that with respect to innovative activity low-tech sectors display the highest degree of clustering within groups of regions. High-tech sectors on the other hand show low coefficients of Moran. When this result is combined with very high Herfindahl indexes for 
these sectors, it can be concluded that high-tech concentrates geographically in only a few regions in Europe, and these clusters do not exceed region borders.

\section{Conclusions}

By means of a new dataset, based on data from the European Patent Office and the REGIO database from Eurostat, the geographic concentration of both innovative and economic activity in Europe has been analyzed. In doing so, innovative activity is proxied by patenting activity by inventor, whereas manufacturing value added at factor costs is used as a proxy of economic activity. In general, regions that have a large spatial concentration of patents also tend to have a large concentration of value added. However, innovative activity is spatially concentrated in fewer regions than value added, which is more evenly spread throughout Europe. If in turn a sectoral perspective is taken, one finds clear evidence of spatial concentrations of innovative as well as economic activity in that for most sectors these variables are more concentrated than population. However, when looking at the country level, even more profound spatial concentration in sectors occurs. The extent to which spatial concentrations are playing a role also differs across sectors, indicating that industry specific as well as country specific conditions determine the spatial pattern of innovation and production.

The mere analysis of concentrations does not give any indication about spillover effects of either innovative or economic activity due to the proximity of one or several active regions. By applying the coefficient of Moran to our dataset, we find that such spillover effects do take place for both types of activity in several sectors. With respect to innovative activity, hightech sectors are found to be highly concentrated in few regions, which are not contiguous.

This paper has been mainly a description of the spatial patterns found with respect to innovative and economic activity across European regions. Therefore it is very difficult to connect policy directives to the findings. However, from a policy perspective it might be interesting to stimulate the various sectoral clusters and broaden them in spatial terms. This could be done by facilitating economic and knowledge spillovers between the centers of the clusters and the regions surrounding them. This should be combined with a support for public infrastructure in the economically backward regions, as was indicated by previous research (Caniëls 1997), since this might make these regions ready to receive and develop the knowledge and the economic development that will spillover to them when it is their time to border upon an innovative and/or economic cluster.

\section{Acknowledgments}

I would like to thank my colleagues Ivo De Loo and Bart Verspagen for fruitful discussions, nevertheless, I take full responsibility for the contents of this paper.

\section{References}

Acs, Z.J., Audretsch D.B. and M.P. Feldman, 1993, 'Innovation and R\&D Spillovers', CEPR Discussion Paper no. 865.

Arthur, W.B., 1990, 'Urban Systems and Historical Path Dependence', in Cities and their Vital Systems, ed. J. Ausubel and R. Herman, pp. 85-97, Washington D.C.: National Academy Press.

Audretsch D.B. and M.P. Feldman, 1994, 'Knowledge Spillovers and the Geography of Innovation and Production', CEPR Discussion Paper no. 953. 
Breschi, S., 1995, 'Spatial Patterns of Innovation: Evidence from Patent Data', paper presented at the workshop on 'New Research Findings: The Economics of Scientific and Technological Research in Europe', Urbino, Italy, 24-25 February 1995.

Buswell, R.J. and E.W. Lewis, 'The Geographical Distribution of Industrial Research Activity in the United Kingdom', Regional Studies, Vol. 4, pp. 297-306.

Caniëls, M.C.J., 1997, 'The Geographic Distribution of Technology Gaps in Europe', paper presented at the EUNIT International Conference, Lisbon, March 20-22, 1997.

Cliff, A.D. and J.K. Ord, 1973, 'Spatial Autocorrelation', London: Pion Limited.

Feldman, M.P., 1994, The Geography of Innovation, Boston: Kluwer Academic Press.

Feldman, M.P. and R. Florida, 1994, 'The Geographic Sources of Innovation: Technological Infrastructure and Product Innovation in the United States', Annals of the Association of American Geographers, Vol. 84(2), pp. 210-229.

Griliches, Z., 1990, 'Patent Statistics as Economic Indicators: A Survey', Journal of Economic Literature, Vol. 28, pp. 1661-1707.

Jaffe, A., Traijtenberg, M. and R. Henderson, 1993, 'Geographic Localization of Knowledge Spillovers as Evidenced by Patent Citations', Quarterly Journal of Economics, pp. 577-598.

Krugman, P., 1991, Economic geography and trade, Cambridge, MA and London: The MIT Press.

Malecki, E.J., 1980, 'Dimensions of R\&D Location in the United States', Research Policy, Vol. 9, pp. 2-22.

McGrew, J.C. and C.B. Monroe, 1993, An Introduction to Statistical Problem Solving in Geography, Dubuque, Iowa: Wm. C. Brown Publishers.

Müller, K. and Nejedly, 1971/1972, 'The Regional Distribution of Research and Development (a note), Research Policy, Vol. 1, pp. 320-328.

Myrdal, G., 1957, Economic theory and under-developed regions, London: Gerald Duckworth \& Co. LTD.

Scherer, F.M., 1983, 'The Propensity to Patent', International Journal of Industrial Organization, Vol. 1, pp. 107-128.

Verspagen, B., 1997, 'European Regional Clubs: Do they exist, and Where Are They Heading? On Economic and Technological Differences between European Regions', paper presented at the $3^{\text {rd }}$ Conference on 'Economic Growth and Change A Comparative Analysis', Cagliari, Italy, June 19-21, 1997.

\section{TABLES}

Table 1: Propensity to patent for 5 European countries

\begin{tabular}{|ll|}
\hline Country & Propensity to patent \\
\hline Spain & 0.39 \\
France & 1.55 \\
Italy & 1.52 \\
The Netherlands & 2.95 \\
United Kingdom & 1.33 \\
\hline
\end{tabular}

Source: EPO, EUROSTAT 
Table2: Distribution of patents and value added by region

\begin{tabular}{|llll|}
\hline & $\begin{array}{l}\text { Share in European } \\
\text { patenting }\end{array}$ & Region & $\begin{array}{l}\text { Share in European } \\
\text { value added }\end{array}$ \\
\hline Ile de France (FR1) & 18.0 & Lombardia (IT2) & 8.3 \\
South East (UK5) & 13.0 & Ile de France (FR1) & 6.5 \\
Lombardia (IT2) & 6.8 & South East (UK5) & 6.5 \\
Rhone-Alpes (FR71) & 6.7 & Piemonte (IT11) & 3.8 \\
Zuid Nederland (NL3) & 6.4 & Cataluna (ES51) & 3.3 \\
West Nederland (NL3) & 4.3 & Veneto (IT32) & 3.3 \\
North West (UK8) & 2.9 & North West (UK8) & 3.2 \\
Piemonte (IT11) & 2.7 & Rhone-Alpes (FR71) & 3.1 \\
West Midlands (UK7) & 2.4 & Emilia-Romagna (IT4) & 3.0 \\
South West (UK6) & 2.3 & West Midlands (UK7) & 3.0 \\
East Anglia (UK4) & 2.2 & West Nederland (NL3) & 2.4 \\
Emilia-Romagna (IT4) & 2.0 & Yorkshire and Humberside (UK2) & 2.4 \\
Total & 69.7 & Total & 48.8 \\
\hline
\end{tabular}

\section{Source: EPO, EUROSTAT}

Table 3: Most important sectors and regions within a country

\begin{tabular}{|c|c|c|c|c|c|c|c|c|}
\hline Country & $\begin{array}{l}\text { Most important } \\
\text { sector according } \\
\text { to patents }\end{array}$ & $\begin{array}{l}\text { Share in } \\
\text { total country } \\
\text { industry }\end{array}$ & $\begin{array}{l}\text { Most } \\
\text { important } \\
\text { regions }\end{array}$ & $\begin{array}{l}\text { Share in } \\
\text { industry }\end{array}$ & \begin{tabular}{|l|} 
Most \\
important \\
sector \\
according to \\
value added
\end{tabular} & $\begin{array}{l}\text { Share in total } \\
\text { country } \\
\text { industry }\end{array}$ & $\begin{array}{l}\text { Most } \\
\text { important } \\
\text { regions }\end{array}$ & $\begin{array}{l}\text { Share in } \\
\text { industry }\end{array}$ \\
\hline \multirow[t]{9}{*}{ Spain } & \multirow[t]{3}{*}{ B24 } & \multirow[t]{3}{*}{$\begin{array}{l}56.3 \\
\end{array}$} & ES51 & 49.9 & \multirow[t]{3}{*}{ B24 } & \multirow[t]{3}{*}{21.7} & ES51 & 28.7 \\
\hline & & & ES3 & 25.6 & & & ES21 & 19.8 \\
\hline & & & ES21 & 6.1 & & & ES3 & 18.7 \\
\hline & \multirow[t]{3}{*}{ B17 } & \multirow[t]{3}{*}{19.2} & ES51 & 52.9 & \multirow[t]{3}{*}{ B36 } & \multirow[t]{3}{*}{19.5} & ES51 & 20.8 \\
\hline & & & ES3 & 28.4 & & & ES61 & 18.2 \\
\hline & & & ES61 & 5.9 & & & ES3 & 9.7 \\
\hline & \multirow[t]{3}{*}{ B28 } & \multirow[t]{3}{*}{11} & ES51 & 60 & \multirow[t]{3}{*}{ B42 } & \multirow[t]{3}{*}{10.3} & ES51 & 38.1 \\
\hline & & & ES3 & 17.2 & & & ES52 & 24.8 \\
\hline & & & ES21 & 8.5 & & & ES3 & 8.4 \\
\hline \multirow[t]{9}{*}{ France } & \multirow[t]{3}{*}{ B24 } & \multirow[t]{3}{*}{64.4} & FR1 & 47.6 & \multirow[t]{3}{*}{ B24 } & \multirow[t]{3}{*}{31} & FR1 & 28.2 \\
\hline & & & FR71 & 15.7 & & & FR71 & 14.7 \\
\hline & & & FR82 & 4.4 & & & FR51 & 5.1 \\
\hline & \multirow[t]{3}{*}{ B17 } & \multirow[t]{3}{*}{15.5} & FR1 & 37.8 & \multirow[t]{3}{*}{ B36 } & \multirow[t]{3}{*}{13.8} & FR1 & 13 \\
\hline & & & FR71 & 22.5 & & & FR52 & 9.1 \\
\hline & & & FR42 & 5.6 & & & FR71 & 8 \\
\hline & \multirow[t]{3}{*}{ B28 } & \multirow[t]{3}{*}{9.5} & FR1 & 49.7 & \multirow[t]{3}{*}{ B28 } & \multirow[t]{3}{*}{12.2} & FR1 & 29.9 \\
\hline & & & FR71 & 8.2 & & & FR43 & 7.7 \\
\hline & & & FR43 & 5.2 & & & FR71 & 6.3 \\
\hline \multirow[t]{9}{*}{ Italy } & \multirow[t]{3}{*}{ B24 } & \multirow[t]{3}{*}{59.1} & IT2 & 38 & \multirow[t]{3}{*}{ B24 } & \multirow[t]{3}{*}{28.8} & IT2 & 33.9 \\
\hline & & & IT11 & 14.1 & & & IT11 & 13.5 \\
\hline & & & IT4 & 13.3 & & & IT4 & 13.5 \\
\hline & B17 & 19.1 & IT2 & 52.7 & B42 & 16.4 & IT2 & 28.2 \\
\hline & & & IT11 & 10.8 & & & IT32 & 15.9 \\
\hline & & & IT4 & 9.2 & & & IT51 & 15.3 \\
\hline & B28 & 9.8 & IT11 & 36.8 & B50 & 10.7 & IT2 & 26.7 \\
\hline & & & IT2 & 31.1 & & & IT32 & 16 \\
\hline & & & IT4 & 8.2 & & & IT11 & 10.8 \\
\hline
\end{tabular}




\begin{tabular}{|c|c|c|c|c|c|c|c|c|}
\hline \multirow[t]{9}{*}{ Netherlands } & B24 & 67.8 & NL4 & 60.2 & B24 & 28.1 & NL4 & 38.8 \\
\hline & & & NL3 & 23.7 & & & NL3 & 33 \\
\hline & & & NL2 & 12.2 & & & NL2 & 20.1 \\
\hline & B17 & 16.7 & NL3 & 56.2 & B17 & 20.1 & NL3 & 50.4 \\
\hline & & & NL4 & 28.2 & & & NL4 & 29.2 \\
\hline & & & NL2 & 12.9 & & & NL2 & 14.1 \\
\hline & B36 & 5.4 & NL3 & 64.1 & B36 & 16.9 & NL3 & 40 \\
\hline & & & NL4 & 20.2 & & & NL4 & 26.4 \\
\hline & & & NL2 & 12 & & & NL2 & 20.9 \\
\hline \multirow[t]{9}{*}{ UK } & B24 & 61.6 & UK5 & 47.3 & B24 & 30.9 & UK5 & 27.9 \\
\hline & & & UK6 & 9.4 & & & UK7 & 15.3 \\
\hline & & & UK4 & 8.9 & & & UK8 & 9.8 \\
\hline & B17 & 20.1 & UK5 & 52.5 & B36 & 13 & UK5 & 19.6 \\
\hline & & & UK8 & 15 & & & UK8 & 13.4 \\
\hline & & & UK2 & 6 & & & UKA & 12.1 \\
\hline & B28 & 7.1 & UK5 & 33.6 & B17 & 10.7 & UK5 & 27.8 \\
\hline & & & UK7 & 23.6 & & & UK8 & 20.9 \\
\hline & & & UK6 & 12.5 & & & UK1 & 11.6 \\
\hline
\end{tabular}

\section{Source: EPO, EUROSTAT}

Inspired by Audretsch and Feldman (1994)

Table 4: Moran per NACE sector

\begin{tabular}{|lllll|}
\hline Sector & \multicolumn{3}{l}{ Patents } & \multicolumn{3}{l|}{ Value added } \\
\hline Ferrous and non-ferrous ores and metals, other than radioactive (B13) & 0.12 & $(1.17)$ & 0.05 & $(0.53)$ \\
Non-metallic minerals and mineral products (B15) & $0.27^{*}$ & $(2.40)$ & 0.19 & $(1.79)$ \\
Chemical products (B17) & $0.27^{*}$ & $(2.46)$ & 0.19 & $(1.77)$ \\
Metal products, machinery, equipment and electrical goods (B24) & $0.29^{*}$ & $(2.59)$ & $0.35^{*}$ & $(3.11)$ \\
Transport equipment (B28) & $0.31^{*}$ & $(2.75)$ & 0.13 & $(1.25)$ \\
Food, beverages, tobacco (B36) & $0.38^{*}$ & $(3.36)$ & 0.18 & $(1.67)$ \\
Textiles and clothing, leather and footwear (B42) & 0.18 & $(1.67)$ & $0.23^{*}$ & $(2.07)$ \\
Paper and printing products (B47) & $0.29^{*}$ & $(2.64)$ & $0.33^{*}$ & $(2.92)$ \\
Products of various industries (B50) & $0.36^{*}$ & $(3.20)$ & $0.32^{*}$ & $(2.89)$ \\
Total (B30) & $0.36^{*}$ & $(3.21)$ & $0.42^{*}$ & $(3.69)$ \\
\hline
\end{tabular}

Values between brackets indicate t-values

* significant at the 5\% level

Source: EPO, EUROSTAT 
Table 5: Coefficient of Moran per ISIC sector

\begin{tabular}{|lll|lll|}
\hline Sector & Moran & \multicolumn{3}{|c|}{ Moran } \\
\hline Instruments (zhi) & $0.29^{*}$ & $(2.60)$ & & & \\
Pharmaceuticals (zcd) & 0.16 & $(1.50)$ & & & \\
Communication equipment and semiconductors (zec) & 0.08 & $(0.82)$ & High-tech & 0.20 & (1.87) \\
Office machines and computers (zho) & 0.05 & $(0.51)$ & & & \\
Aerospace (zae) & 0.01 & $(0.21)$ & & & \\
\hline Industrial chemicals (zcc) & $0.29^{*}$ & $(2.58)$ & & \\
Non-electrical machinery (zhn) & $0.39^{*}$ & $(3.49)$ & & & \\
Electrical machinery (zem) & 0.10 & $(0.99)$ & Medium Tech & $0.37^{*}$ & $(3.30)$ \\
Motor vehicles (ztm) & $0.29^{*}$ & $(2.58)$ & & & \\
Other transport (zto) & $0.26^{*}$ & $(2.36)$ & & & \\
\hline Stone, clay and glass (zog) & $0.27^{*}$ & $(2.40)$ & & & \\
Non-ferrous metals (zmn) & 0.18 & $(1.65)$ & & & \\
Petroleum refineries (zcp) & $0.23^{*}$ & $(2.05)$ & & \\
Rubber and plastics (zlr) & $0.36^{*}$ & $(3.19)$ & & \\
Basic metals (zmd) & $0.49^{*}$ & $(4.34)$ & & \\
Ferrous metals (zmf) & 0.08 & $(0.82)$ & Low Tech & \\
Shipbuilding (zti) & 0.15 & $(1.41)$ & & \\
Food, drink and tobacco (zlf) & $0.38^{*}$ & $(3.36)$ & & \\
Textiles, footwear and leather (zlx) & 0.18 & $(1.67)$ & & \\
Wood, cork and furniture (zow) & $0.29^{*}$ & $(2.64)$ & & \\
Other manufacturing industries (zoo) & $0.35^{*}$ & $(3.12)$ & & \\
Paper and printing (zop) & $0.27^{*}$ & $(2.42)$ & & & \\
\hline
\end{tabular}

Values between brackets indicate t-values

* significant at the $5 \%$ level

Source: EPO 


\section{FIGURES}

Figure 1: Share in European patenting

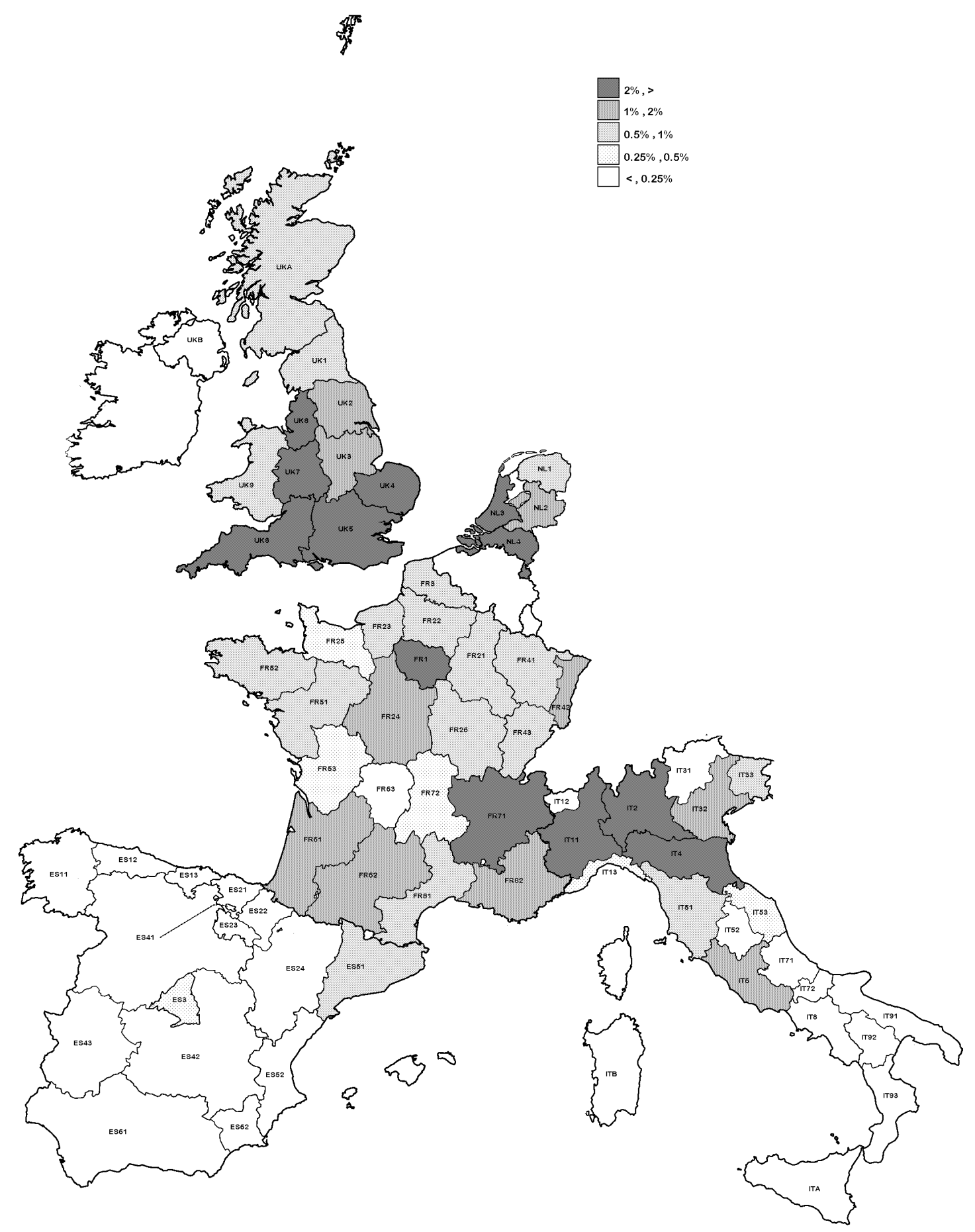

Source: EPO 
Figure 2: Share in European manufacturing value added

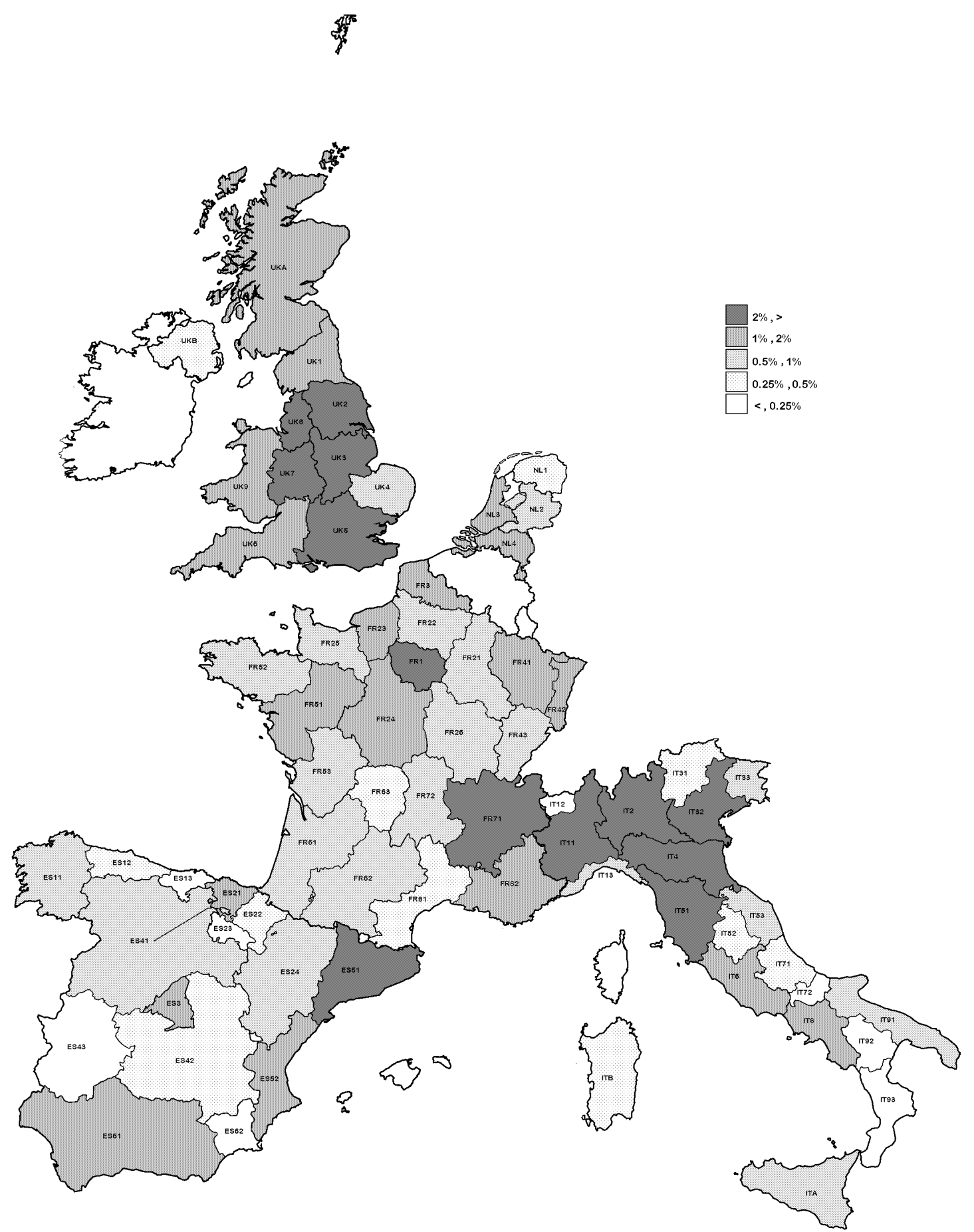

Source: EUROSTAT 
Figure 3: Patents corrected for population

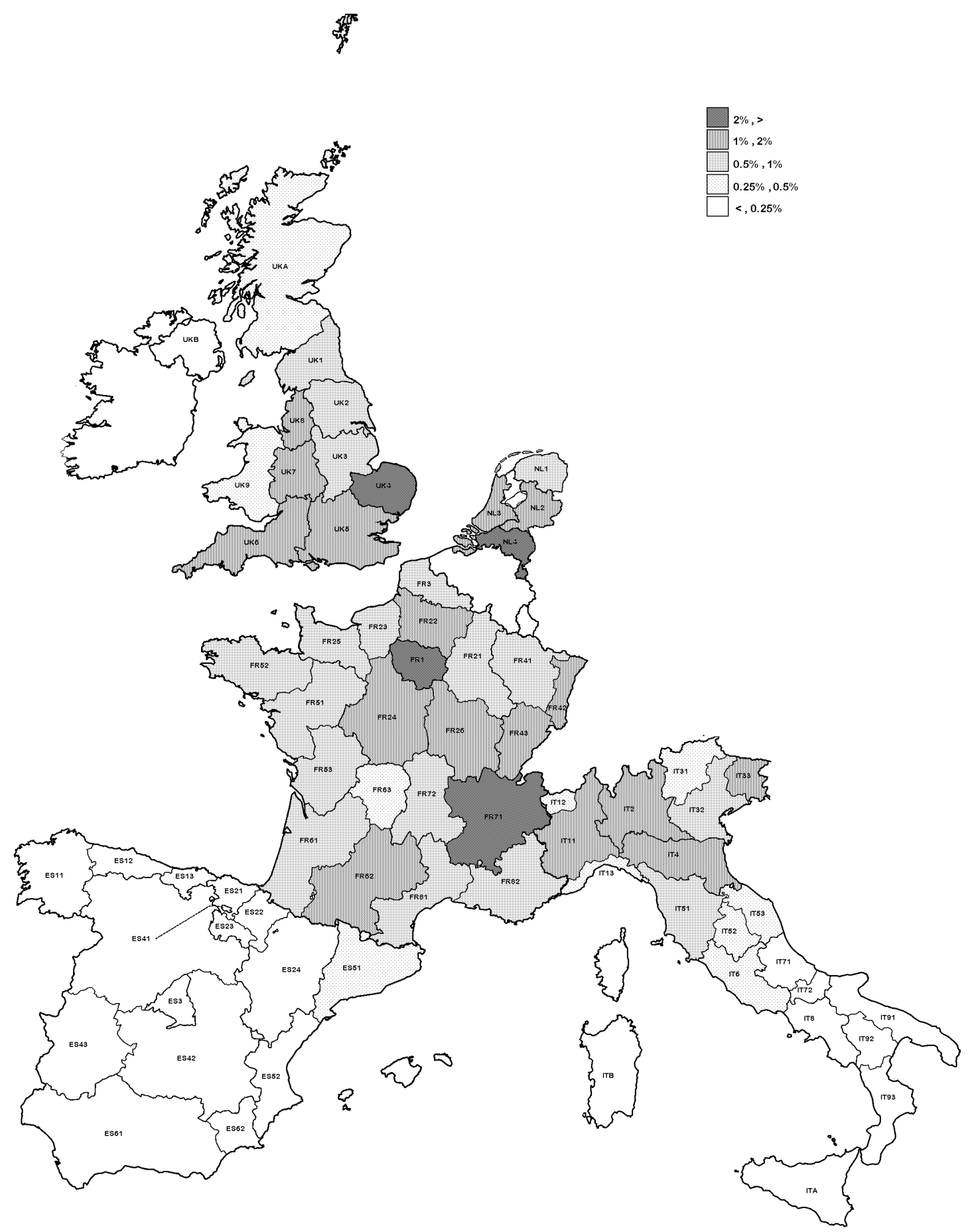

Source: EPO, EUROSTAT 
Figure 4: Value added corrected for population

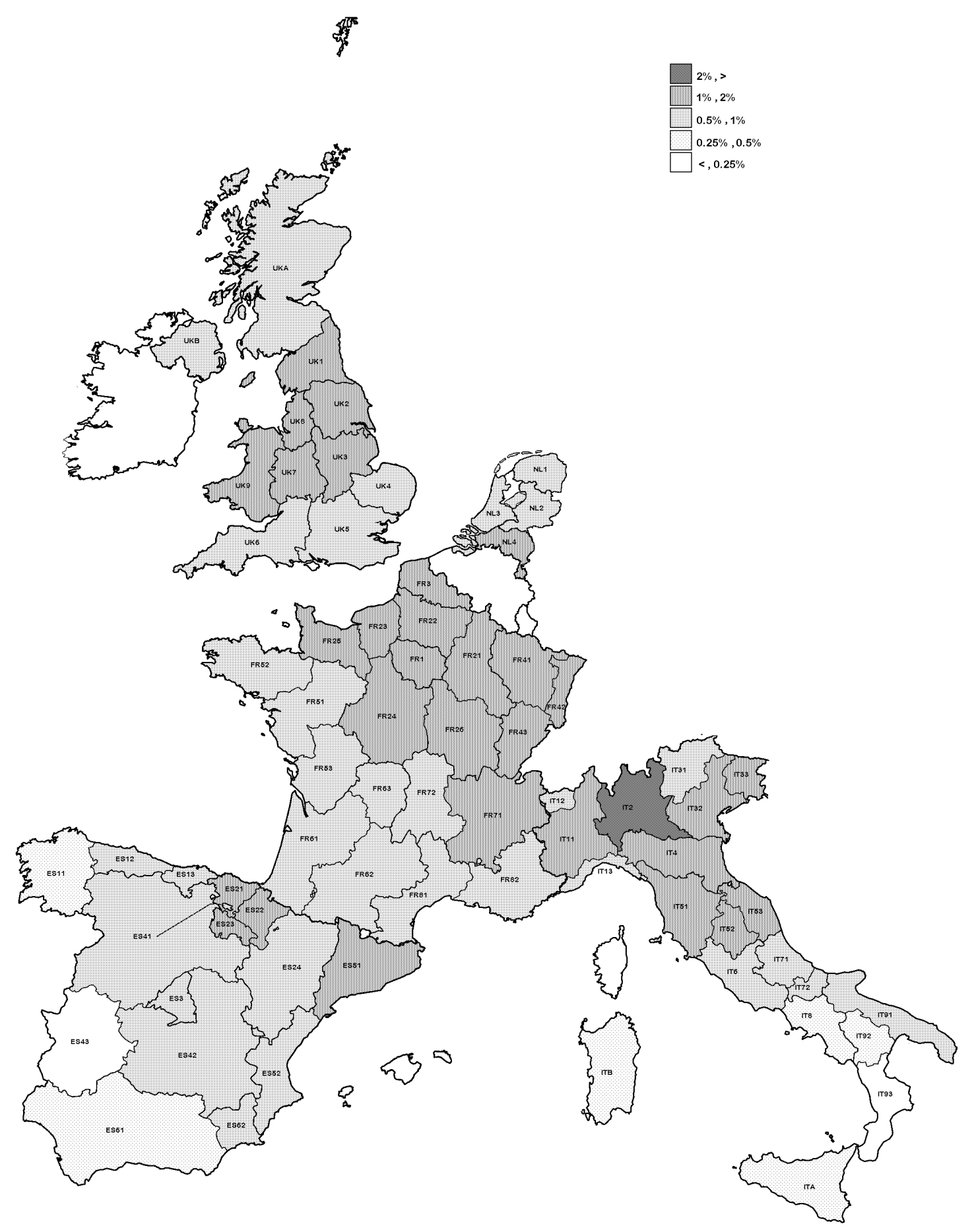

Source: EUROSTAT 


\section{Figure 5: Herfindahl index for Europe per sector}

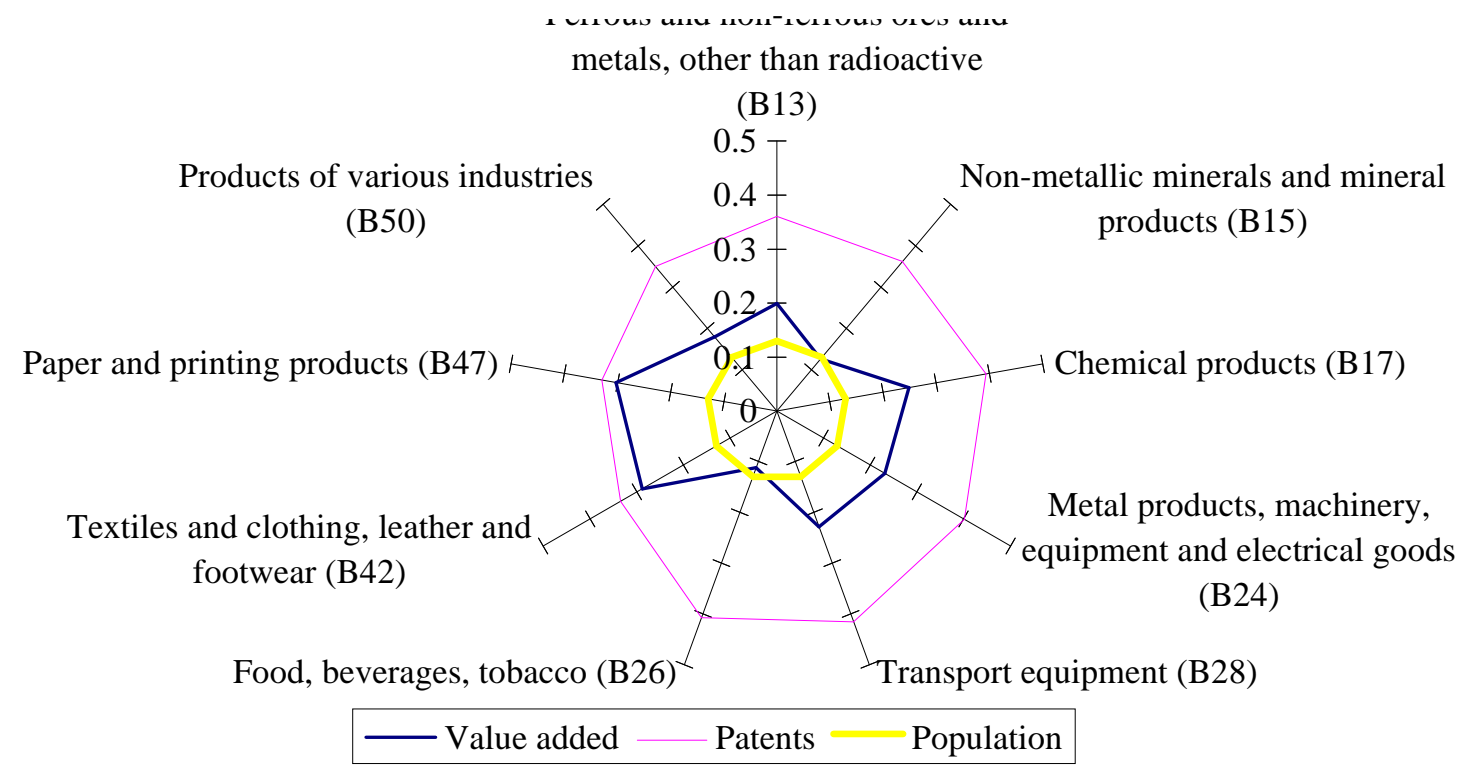

Source: EPO, EUROSTAT

Figure 6: Herfindahl index for each country per sector

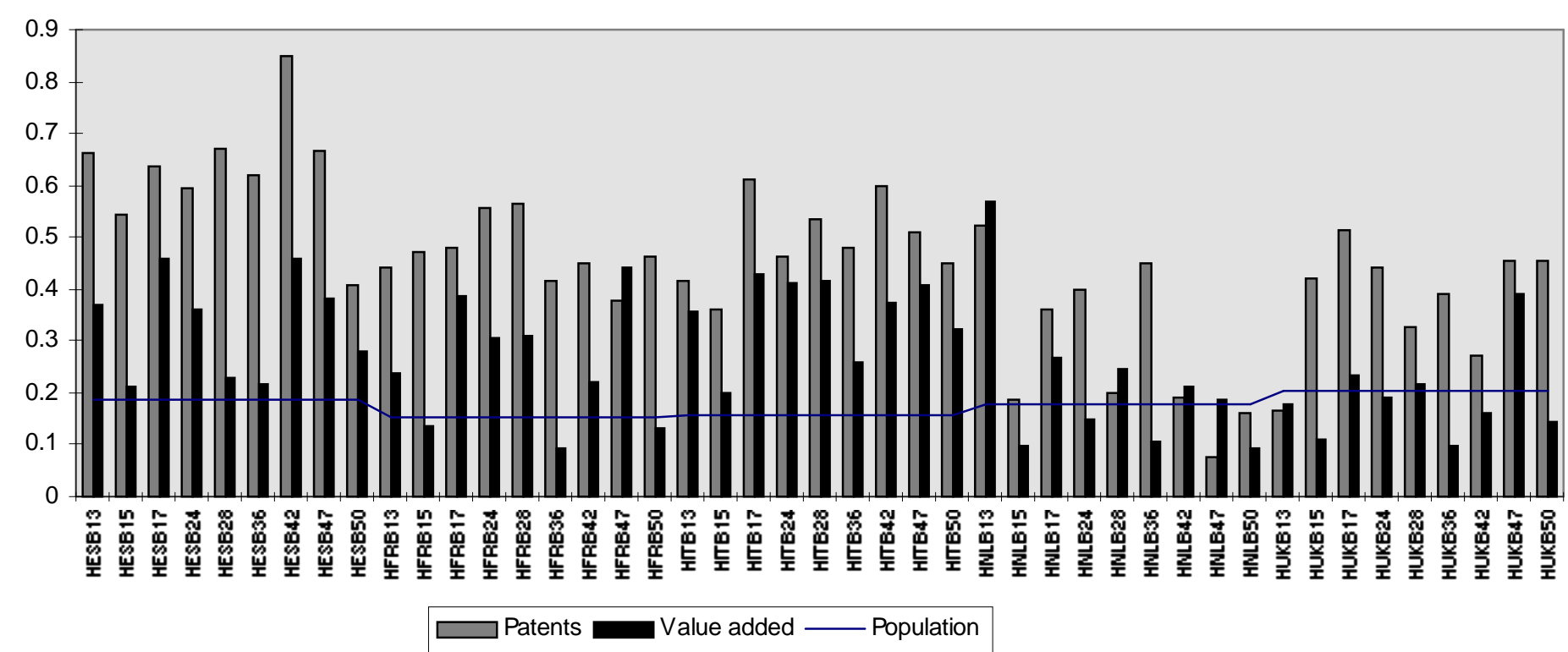

Source: EPO, EUROSTAT 
Figure 7: Spatial Patterns

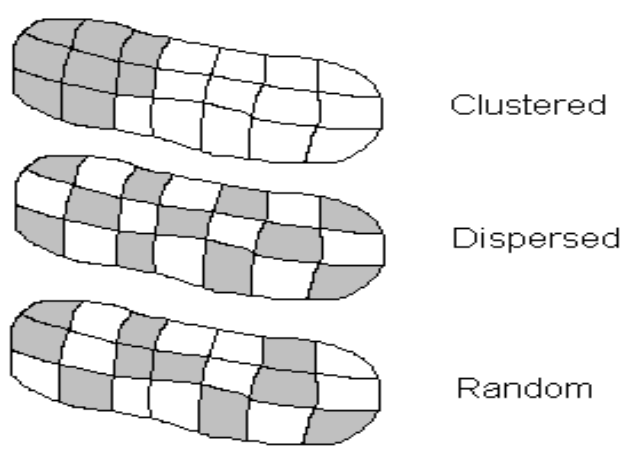

Inspired by McGrew and Monroe (1993)

Figure 8: Coefficient of Moran for the total of all sectors

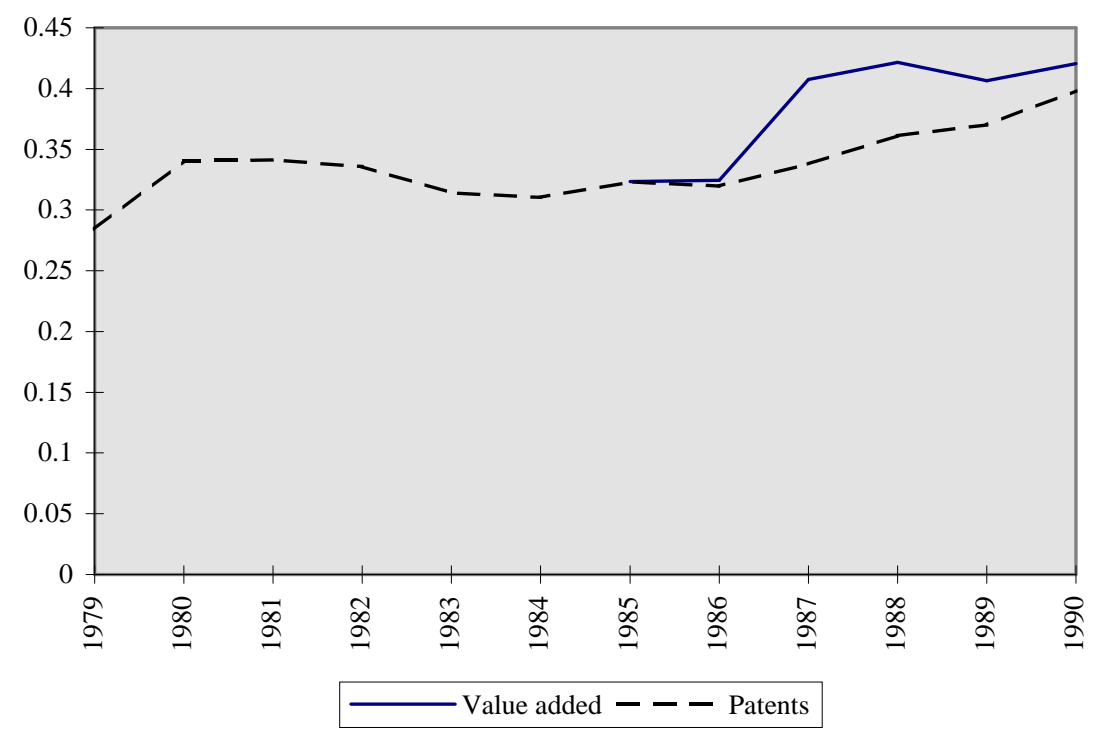

Source: EPO, EUROSTAT 


\section{Figure 9: Herfindahl index for all ISIC sectors at the European level}

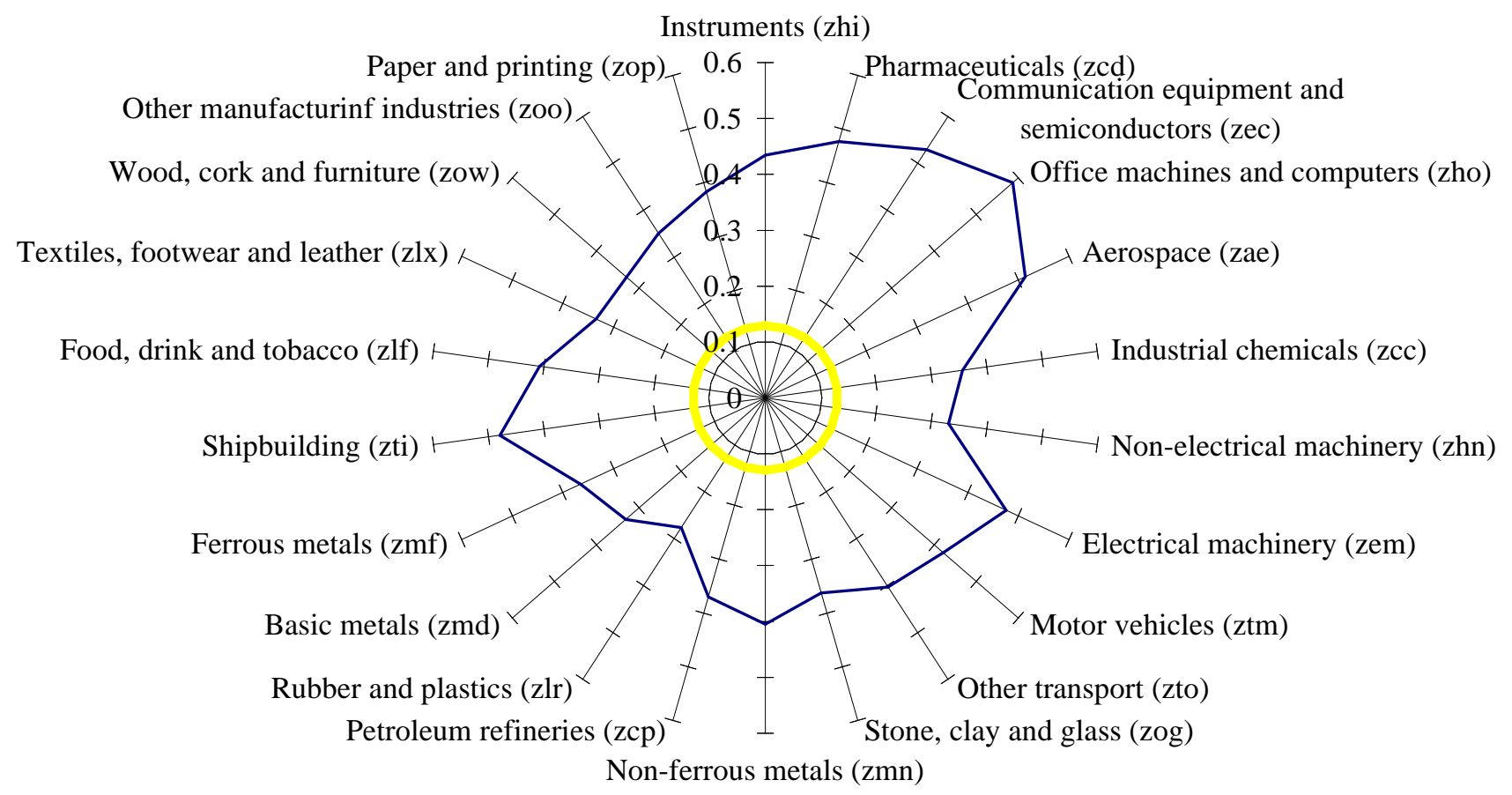

\section{Source: EPO, EUROSTAT}




\section{Appendix I: NACE Classification}

B13 Ferrous and non-ferrous ores and metals, other than radioactive

B15 Non-metallic minerals and mineral products

B17 Chemical products

B24 Metal products, machinery, equipment and electrical goods

B28 Transport equipment

B36 Food, beverages, tobacco

B42 Textiles and clothing, leather and footwear

B47 Paper and printing products

B50 Products of various industries

\section{Appendix II: Regions used in the analysis}

\begin{tabular}{|c|c|c|c|}
\hline No. & NUTS & Country & Region \\
\hline 1 & ES11 & Spain & Galicia \\
\hline 2 & ES12 & Spain & Principado de Asturias \\
\hline 3 & ES13 & Spain & Cantabria \\
\hline 4 & ES21 & Spain & Pais Vasco \\
\hline 5 & ES22 & Spain & Comunidad Foral de Navarra \\
\hline 6 & ES23 & Spain & La Rioja \\
\hline 7 & $\mathrm{ES} 24$ & Spain & Aragón \\
\hline 8 & ES3 & Spain & Comunidad de Madrid \\
\hline 9 & ES41 & Spain & Castilla y León \\
\hline 10 & ES42 & Spain & Castilla-la Mancha \\
\hline 11 & ES43 & Spain & Extremadura \\
\hline 12 & ES51 & Spain & Cataluña \\
\hline 13 & ES52 & Spain & Comunidad Valanciana \\
\hline 14 & ES61 & Spain & Andalucia \\
\hline 15 & ES62 & Spain & Región de Murcia \\
\hline 16 & ES7 & Spain & Canarias \\
\hline 17 & FR1 & France & Ile de France \\
\hline 18 & FR21 & France & Champagne \\
\hline 19 & FR22 & France & Picardie \\
\hline 20 & FR23 & France & Haute Normandie \\
\hline 21 & FR24 & France & Centre \\
\hline 22 & FR25 & France & Basse Normandie \\
\hline 23 & FR26 & France & Bourgogne \\
\hline 24 & FR3 & France & Nord - Pas-de Calais \\
\hline 25 & FR41 & France & Lorraine \\
\hline 26 & FR42 & France & Alsace \\
\hline 27 & FR43 & France & Franche-Comté \\
\hline 28 & FR51 & France & Pays de la Loire \\
\hline 29 & FR52 & France & Bretagne \\
\hline 30 & FR53 & France & Poitou-Charentes \\
\hline 31 & FR61 & France & Aquitaine \\
\hline 32 & FR62 & France & Midi-Pyrénées \\
\hline 33 & FR63 & France & Limousin \\
\hline 34 & FR71 & France & Rhône-Alpes \\
\hline 35 & FR72 & France & Auvergne \\
\hline 36 & FR81 & France & Languedoc-Roussillon \\
\hline 37 & FR82 & France & Provence-Alpes-Côte d'Azur \\
\hline 38 & IT11 & Italy & Piemonte \\
\hline 39 & IT12 & Italy & Valle d'Aosta \\
\hline 40 & IT13 & Italy & Liguria \\
\hline 41 & IT2 & Italy & Lombardia \\
\hline 42 & IT31 & Italy & Trentino-Alto Adige \\
\hline
\end{tabular}




$\begin{array}{llll}43 & \text { IT32 } & \text { Italy } & \text { Veneto } \\ 44 & \text { IT33 } & \text { Italy } & \text { Friuli-Venez. Giulia } \\ 45 & \text { IT4 } & \text { Italy } & \text { Emilia-Romagna } \\ 46 & \text { IT51 } & \text { Italy } & \text { Toscana } \\ 47 & \text { IT52 } & \text { Italy } & \text { Umbria } \\ 48 & \text { IT53 } & \text { Italy } & \text { Marche } \\ 49 & \text { IT6 } & \text { Italy } & \text { Lazio } \\ 50 & \text { IT71 } & \text { Italy } & \text { Abruzzo } \\ 51 & \text { IT72 } & \text { Italy } & \text { Molisse } \\ 52 & \text { IT8 } & \text { Italy } & \text { Campania } \\ 53 & \text { IT91 } & \text { Italy } & \text { Puglia } \\ 54 & \text { IT92 } & \text { Italy } & \text { Basilicata } \\ 55 & \text { IT93 } & \text { Italy } & \text { Calabria } \\ 56 & \text { ITa } & \text { Italy } & \text { Sicilia } \\ 57 & \text { ITb } & \text { Italy } & \text { Sardegna } \\ 58 & \text { NL1 } & \text { The Netherlands } & \text { Noord-Nederland } \\ 59 & \text { NL2 } & \text { The Netherlands } & \text { Oost-Nederland } \\ 60 & \text { NL3 } & \text { The Netherlands } & \text { West-Nederland } \\ 61 & \text { NL4 } & \text { The Netherlands } & \text { Zuid-Nederland } \\ 62 & \text { UK1 } & \text { United Kingdom } & \text { North } \\ 63 & \text { UK2 } & \text { United Kingdom } & \text { Yorkshire and Humberside } \\ 64 & \text { UK3 } & \text { United Kingdom } & \text { East Midlands } \\ 65 & \text { UK4 } & \text { United Kingdom } & \text { East Anglia } \\ 66 & \text { UK5 } & \text { United Kingdom } & \text { South East } \\ 67 & \text { UK6 } & \text { United Kingdom } & \text { South West } \\ 68 & \text { UK7 } & \text { United Kingdom } & \text { West Midlands } \\ 69 & \text { UK8 } & \text { United Kingdom } & \text { North West } \\ 70 & \text { UK9 } & \text { United Kingdom } & \text { Wales } \\ 71 & \text { UKa } & \text { United Kingdom } & \text { Scotland } \\ 72 & \text { UKb } & \text { United Kingdom } & \text { Northern Ireland } \\ & & \end{array}$

${ }^{1}$ See Appendix II for the NUTS classification used in this paper.

${ }^{2}$ Germany was not include since there were no data on value added available.

${ }^{3}$ It would have been preferable to correct patents by manufacturing employment. However, since the correlation between population and manufacturing employment is very high (the correlation does not differ significantly from 1 at the $5 \%$ significance level) this would probably not have made much difference.

${ }^{4}$ The $\ln$ function is used to give the index a gradual increase (decline) when the extent of concentration gradually becomes more (less).

${ }^{5}$ The variables used are all corrected for population density. $n$ is regarded as the total number of regions in Europe.

${ }^{6}$ For a description of the NACE CLIO sector codes, see Appendix I.

${ }^{7}$ Not yet documented.

${ }^{8}$ In the calculation of the coefficient of Moran, we only took into account the neighbours up till the fourth order, since beyond that distance we do not expect any spillovers due to geographic proximity. 